\title{
Når militæret skriver krigshistorier
}

\section{En analyse af David Abrams' Fobbit}

Juni 2005. Chance Gooding Jr. er halvvejs gennem sin udsendelse i Irak. Han har aldrig affyret sit våben eller været i ildkamp, og det kommer han heller ikke, for mens hans kollegaer sætter livet på spil i Bagdads gader, kæmper han en anden kamp: kampen om offentlighedens opfattelse af Irakkrigen. Som public affairs officer i den amerikanske hær er det hans opgave at skrive pressemeddelelser om krigens gang. Iscenesættelse er altafgørende, lyder det fra Goodings overordnede, der frygter for offentlighedens følelsesmæssige reaktion på nyhederne fra slagmarken. At repræsentere krig er i deres øjne et redskab til affektiv kontrol, og hvert ord og sætning overvejes nøje i forsøget på at tegne et billede af krigen, som sikrer befolkningens opbakning.

Chance Gooding Jr. er hovedpersonen i David Abrams' roman, Fobbit (2012), hvis handling er inspireret af hans karriere som journalist i hæren. Gooding er ikke den eneste presseofficer, som dukker op i repræsentationerne af krigene i Irak og Afghanistan. Andre eksempler er Phil Klays "Money as a Weapons System" fra novellesamlingen Redeployment (2014) og David Michôds film War Machine (2017). Men Fobbit adskiller sig fra de to andre værker, da den fokuserer på presseofficerens arbejde som krigskronikør og de narrative strategier, militæret bruger, når krigen skal iscenesættes.

En krigsroman om forholdet mellem krig og fortælling er langt fra et nyt fænomen, men hvad er de unikke fortællemæssige udfordringer ved de historiske omstændigheder, romanen adresserer? Og hvorfor er det så magtpåliggende for militæret at kontrollere billedet af krigen i offentligheden? Det er nogle af de spørgsmål, jeg vil diskutere i første del af denne artikel. Fobbits fokus på forholdet mellem krigsfremstillingen og folkestemningen leder tankerne hen på Vietnamkrigen. Pressehistorisk var denne krig unik. Ikke blot fordi Vietnam var den første tv-transmitterede krig, men også fordi journalisterne havde fri adgang til slagmarken, og censuren var fraværende. Selv om det kan diskuteres i hvor høj grad, det var pressens omfattende dækning af krigens rædsler, der gav næring til den voksende modvilje mod ameri- 
kanernes militære tilstedeværelse i Fjernøsten, så er det den historie, som oftest fortælles. Når det er blevet sådan, skyldes det formentlig, at Pentagon i landets senere krige har forsøgt at begrænse pressens adgang til krigszonen i bestræbelsen på at genvinde kontrollen med pressens krigsfremstilling og derigennem har bekræftet fortællingen (Lewis 2018, 266f). Fobbit er en beretning om, hvorledes det står til med militærets fors $\varnothing g$ på at genvinde kontrollen, og konklusionen er utvetydig: Konfronteret med det 21. århundredes medielandskab kæmper militæret en kamp, der ikke kan vindes. Abrams' roman sætter dog spørgsmålstegn ved, om det overhovedet er nødvendigt at vinde denne kamp i dag, for Irakkrigen er som bekendt ikke blevet det nye årtusindes Vietnam.

Det billede af Irakkrigen, som kommer til syne gennem Fobbits historier om militærets kontrolforsøg, er på mange måder identisk med det billede, som læserne kender fra mediernes dækning af krigen. Ser man på tidligere værker, der tematiserer militærets krigsfremstilling - et eksempel kunne være Leo Tolstojs Krig og fred (1867) - så har disse værker skullet fungere som et korrektiv til den officielle historie. Men hvis pressen allerede har korrigeret den historie om krigen, som militæret forsøger at fortælle, hvad kan romanen så bidrage med? Hvor kan litteraturen som metarepræsentation sætte ind og med hvad, når den korrigerende fortælling allerede er skrevet? Med latter! Abrams har skrevet en satirisk komedie om det amerikanske krigsmaskineri. Netop valget af komik gør Fobbit til et interessant særtilfælde, for hovedparten af fortællingerne om Irak og Afghanistan er holdt i en realistisk tone, og perspektivet er den hjemvendte soldats, og krigsoplevelserne præsenteres som mere eller mindre traumatiske flashbacks. ${ }^{\mathrm{I}}$ Men hvilket kritisk potentiale har latteren? Disse spørgsmål er omdrejningspunktet i artiklens anden del, hvor jeg ikke blot diskuterer, hvilken plads krigslitteraturen kan indtage blandt de mange fortællinger om krigen, som allerede cirkulerer, men også overvejer årsagerne til, at Fobbit ikke lykkes med at indtage denne plads.

\section{Ord som kontrolredskab}

Tematiseringen af forholdet mellem krig og fortællinger gennemsyrer Fobbit. Ud over de pressemeddelelser, som Gooding skriver, præsenteres læseren for dagbogsuddrag, som er beslægtet med fortællerens spydige tone og indstilling til krigen. I tillæg er der e-mailkorrespondancer fra hærens kommunikationsafdeling om brugen af ord som terrorist og insurgent, samt lange e-mails som Goodings overordnede, Hackleroad, sender til sin mor for at fortælle hende om sine bedrifter: som en anden Achilleus vender han tilsyneladende fiaskoer til succeser og kommer egenhændigt sårede soldater til undsætning. Ingen af hans historier har dog hold i virkeligheden. I stedet er der tale om løgne spundet over heroiske klicheer. Uoverensstemmelsen mellem virkelighed og realitet i Hackleroads mail gentager sig i Goodings pressemeddelelser. Men i modsætning til Hackleroad, der beder sin mor om ikke at fortælle offentligheden om sine bedrifter for at undgå at blive afsløret som løgner, så bliver Goodings historier hele tiden draget i tvivl af medierne.

Udgangspunktet for analysen af militærets iscenesættelsesstrategier er romanens tredje kapitel, hvor læseren tages igennem "the life cycle of a typical press 
release" (Abrams 2014, 63). Denne livscyklus begynder, når Gooding modtager en rapport fra slagmarken, en såkaldt Sig Act- eller Significant Action-rapport, som placerer hændelserne i tid og rum og kortfattet, men også relativt detaljeret, informerer om, hvad der er sket samt om antallet af døde og sårede:

6 SOLDIERS ON MOUNTED PATROL TRAVELING IN VICINITY OF AL-KARKH WATER PLANT FLAGGED DOWN BY IRAQI CITIZEN CLAIMING AN IED 200 METERS AHEAD. SSG HARDING AND TWO OTHER MEMBERS OF THE PATROL DISMOUNTED M1114 TO SEARCH FOR IED EVIDENCE. TWO ADDITIONAL SOLDIERS SEARCHED ADJACENT FIELDS FOR WIRES, BAGS OF GARBAGE, ANIMAL CORPSES, ETC. INDICATING LOCATION OF IED. SSG HARDING ALSO WALED FORWARD, BUT REMAINED ON THE ROAD. IED WAS ONLY 30 METERS AHEAD OF SOLDIERS. AS TEAM MOVED FORWARD, IED EXPLODED, CAUSING IMMEDIATE AMPUTATION OF SSG HARDING'S FOUR LIMBS. FRAGMENTS OF IED ALSO PENETRATED SSG HARDING'S HELMET, RESULTING IN MASSIVE HEAD INJURY AND SUBSEQUENT DEATH. UNIT CONDUCTED IMMEDIATE CORDON AND SEARCH FOLLOWING THE ATTACK TO FIND RESPONSIBLE PARTY OR PARTIES AND DETAINED FOR FURTHER QUESTIONING ONE POSSIBLE WITNESS, THE INDIVIDUAL WHO ORIGINALLY WARNED THEM ABOUT THE IED. (Abrams 2014, 6)

Det er Goodings opgave at omforme Sig Act-rapporter som ovenstående til pressemeddelelser, der ser sådan ud:

\section{FOR IMMEDIATE RELEASE}

JUNE 6, 2005

\section{RELEASE 20050606-04A}

Soldier killed in al-Karkh suicide car bomb blast

BAGHDAD - A Task Force Baghdad soldier was killed when a suicide car bomber detonated his payload in an al-Karkh neighborhood around 11 a.m. on June 6.

Three Iraqi bystanders were also killed in the blast, which ripped through a shopping district, destroying a tea shop and a fruit seller's stall.

The soldier's unit was assisting Iraqi security forces on a patrol of the area when it came under attack from terrorists. The soldier was evacuated to the 86th Combat Support Hospital where he later died of his injuries.

The name of the soldier is being held pending notification of next of kin. The incident is under investigation. (Abrams 2014, 65f)

Formmæssigt adskiller Sig Act-rapporterne sig fra Goodings pressemeddelelser på en række punkter. Blokbogstavernes "shouting in military jargon" (Abrams 2014, 6) er blevet erstattet med små bogstaver, og linjeskift gør det lettere at overskue informationerne. For god ordens skyld skal det nævnes, at den citerede Sig Act-rapport ikke er udgangspunktet for den pressemeddelelse, som diskuteres her. Det skyldes, at Sig-Act-rapporten om begivenhederne i al-Karkh den 6. juni 2005 ikke figurerer i romanen; en anden rapport måtte derfor bruges for at illustrere den visuelle forskel. Gooding parafraserer dog dele af rapporten fra den 6. juni og indvier dermed læseren i den amerikanske soldats død: 
64 a hot chunk of scrap iron finding that two-inch sweet spot between the helmet and the collar of the flak vest and ripping away half of the kid's neck, causing him to stumble and trip into a puddle of ignited gasoline. Three others had been wounded with the usual assortment of burns, partial amputations, and concussions. (Abrams 2014, 59)

Sammenlignes pressemeddelelsen med den første Sig Act-rapport og Goodings parafrase af samme, bliver det tydeligt, at en række detaljer, heriblandt de grafiske detaljer om soldaternes endeligt, forsvinder i Goodings bearbejdning. Pressemeddelelsens krigsfremstilling er ikke blot en simplificering, men også en fremstilling renset for blod og vold. I første omgang nævnes det, at eksplosionen dræbte tre civile irakere og ødelagde kvarterets butikker, men disse detaljer udelades i den endelige version. Først beder Goodings overordnede, Hackleroad, ham nemlig om at slette "the part about the shopping district and the fruit and tea" og derefter om at fjerne "all reference to dead Iraqis." Hackleroad frygter, at henvisningen til frugt og te vil menneskeliggøre irakerne, og de afdøde civile bør ikke nævnes, fordi "collateral deaths are always a tricky thing" (Abrams 2014, 67).

I tillæg til udslettelsen af et irakisk hverdagsliv i pressemeddelelsen bliver Sig Act-rapportens nøgterne beskrivelser af begivenhederne også mere ladede for hver gennemskrivning. De irakiske sikkerhedsstyrker omtales først som heroiske, og det fremhæves, at de klarer sig med "minimal assistance" fra amerikanerne. I sidste udgave af pressemeddelelsen har det udviklet sig til en historie om modige og dristige irakiske sikkerhedsstyrker, der "repel heinous al-Karkh attack" med "lightning-like speed and efficiency" (Abrams 2014, 74). Denne passage er - sammen med Hackleroads løgnehistorier om diverse heltemodige bedrifter - et bidrag til diskussionen om det heroiske, og romanen må med Sibylle Sheipers ord siges at abonnere på en forståelse af heroisme som "a continuous process of social construction rather than the performance of an individual courage act" (Scheipers 2014, 5). Gooding og Hackleroads arbejde med pressemeddelelsen tydeliggør også, at formålet med hærens krigsskriverier ikke er at fortælle, hvad der faktisk skete. Tværtimod er det, ifølge Gooding selv, hans job at omformulere Sig Act-rapporternes skrigende militære jargon til "something palatable-ideally, something patriotic-that the American public could stomach as they browsed the morning newspaper with their toast and eggs" (Abrams 2014, 2).

Som Sianne Ngai påpeger i sin bog om følelser og æstetik, Ugly Feelings (2005), finder vi allerede hos Aristoteles en forståelse for, at publikums følelsesmæssige respons udspringer af tragediens komposition. Plottet, skriver Aristoteles, "bør være komponeret sådan, at selv uden at se det vil den, der blot hører de hændelser, der forekommer, gyse og lide ved det, der sker" (Aristoteles 2008, 74 (1453b)). Ligesom ovenfor, hvor det heroiske er et produkt af iscenesættelsen, så er Aristoteles' - og med ham Ngais - pointe, at de følelser, som et kunstværk vækker i modtageren, er resultatet af en række kompositoriske greb, af præsentationsformen. At kalde Goodings pressemeddelelser kunst vil være en tilsnigelse, men fortællingen om "the life cycle of a typical press release" samt de mange e-mails fra overordnede om korrekt ordvalg afslører, at hærens presseafdeling er bevidst om sammenhængen mellem krigsfremstillingens karakter og modtagernes reak- 
tioner. Militæret forsøger med andre ord at anvende sproget til at udføre en form for følelsesmæssig kontrol. Vrede og afsky skal for alt i verden undgås; folk skal ikke samle sig i modstand, som det var tilfældet med Vietnamkrigen. Begivenhedernes gang må derfor præsenteres på en sådan måde, at offentligheden kan synke historierne fra krigszonen uden at få æg og brød galt i halsen. Sagt med andre ord skal Gooding sørge for, at krigen bliver så spiselig, at amerikanerne kan leve med, at den finder sted.

\section{Kampen om forståelsen}

I Watching War (2012) argumenterer Jan Mieszkowski for, at alle, der repræsenterer krig, deltager i en kamp om, hvorledes denne krig skal forstås, og han viser, hvordan krigen allerede under Napoleon - og ikke først i det 20. århundrede - udviklede sig til et fænomen, som masserne skulle følge med i (Mieszkowski 2012, 1). De franske magthavere udnyttede de trykte mediers opblomstring til at sprede deres fortælling om krigen og derigennem sikre sig folkets opbakning. De kontrollerede ikke blot avisernes dækning, men udgav også selv bulletiner, som i propagandistiske og heroiske vendinger roste den franske hærs bedrifter. Med henvisning til datidige bemærkninger om disse kilder påpeger Mieszkowski, at "this mass propaganda was accompanied by skepticism about the 'official story"' (Mieszkowski 2012, 10). Men brugen af de trykte medier viser også, at datidens militær i lige så høj grad som nutidens militærfolk vidste, at "to 'win' a battle was as much to secure control of the story in the popular imagination as to rout the opponent's forces or take control of a particular locale" (Mieszkowski 2012, 5).

Et eksempel på et ældre værk, som bl.a. adresserer forholdet mellem militærets krigsfortællinger og krigens realiteter, er Leo Tolstojs Krig og fred (1867). Efter at have ført en eskadron husarer til sejr berømmes Nikoláj Rostóv for sin tapperhed og tildeles Sankt Georgskorset. Rostóv selv modtager beskeden med forbavselse. "Det er altså bare det, man kalder heroisme? Gjorde jeg det måske for fædrelandet? [...] Det gav et ryk i min arm. Og så fik jeg Sankt Georgskorset" (Tolstoj 2004, 71). Som med eksemplet ovenfor fra Fobbit illustrerer også denne episode, at det heroiske ikke er en kvalitet ved individets handlinger, men tilskrives begivenhederne efterfølgende. Det bliver også ekstra tydeligt, hvis beretningen om Rostóvs møde med en fransk officer tages med i betragtning. Tolstoj skriver, at Rostov løfter armen "uden selv at vide hvorfor", og dermed bliver det sår, han tilføjer franskmanden, alt andet end en viljesakt. Ligeledes er det heller ikke det velplacerede sabelhug, som får den franske officer til at falde af hesten, men derimod sammenstødet mellem Rostóvs og franskmandens hest.

Selvom historien om Sankt Georgskorset ikke omhandler militærets kontrol med pressens krigsfremstilling, så peger episoden på, at militæret har kontrol over den officielle fortællingen om, hvad der sker på slagmarken. Og deres version virker: Ophøjelsen af Rostóv til krigshelt fører ikke blot til en forfremmelse og gør ham til førstevalget, når særligt farlige angreb skal gennemføres. Historien om hans heroiske bedrifter bliver også den historie, det russiske samfund hører. Tolstojs roman fremhæver et centralt element i krigen: kampen om kontrollen med 
krigsfortællingen. I Krig og fred har militæret succes med at kontrollere den officielle historie om krigen; i Fobbit er situationen en anden, og en af årsagerne er det ændrede medielandskab.

Som blandt andre Stacey Peebles har påpeget, gør moderne kommunikationsteknologier det sværere for militæret at kontrollere nyhedsstrømmen fra krigszonen. I tillæg til de store mediehuse, som bringer nyheder fra verdens brændpunkter samtidig med, at de udspiller sig, fortæller civile fanget i krigszonen og soldater også om krigen i e-mails, på blogs og via sociale netværk (Peebles 2011, 9f). De personlige beretninger om krigen figurerer dog ikke i Fobbit, der udelukkende fokuserer på, hvordan nyhedsmediernes arbejdsgange overflødiggør Goodings arbejde. Beretningen om "the life cycle of a typical press release" ender med, at CNN med hjælp fra lokale kilder fortæller en helt anden historie om begivenhederne ved al-Karhk, end den Gooding skriver. Hærens regler for, hvornår visse oplysninger må offentliggøres samt de evindelige sproglige korrektioner, medfører, at pressemeddelelserne ikke blot bliver "a mere afterthought in the grand scheme of things", men ender "as some editor's paper basketball arcing through the air into a wastebasket in a news room somewhere in South Dakota" (Abrams 2014, 276, 366). CNN's journalist, der skal live igennem til USA, har ikke tid til at vente på Gooding. Det behøver hun heller ikke, for i modsætning til hærens presseofficerer befinder hun sig midt i Bagdad sammen med de amerikanske tropper og på baggrund af, hvad hun har set og hørt, fortæller hun præcis det, som militæret ikke ønsker, offentligheden skal høre.

\section{Den overflødige iscenesættelse}

Fobbit illustrerer Mieszkowskis pointe om, at alle, der repræsenterer kamp, deltager i en kamp om krigsopfattelsen. Men som krigsrepræsentation er romanen selv - i lighed med Krig og fred - en kombattant i denne kamp. Hos Tolstoj tjener de mange episoder om diskrepansen mellem krigens realiteter og dens fremstilling i romanen ikke blot som et korrektiv til den officielle krigshistorie, men også til at indvie læseren i den generelle sandhed om alle krigsfortællinger: De er aldrig sande. Men hvad med Fobbit? Eftersom Goodings job består i at rense krigen for blod, vold og destruktion, så bidrager hans arbejde til at opretholde det billede af krigen, som politikere og militæret har fors $\varnothing$ gt at tegne af både Irak- og Afghanistankrigen som moralsk rigtige og mindre skadelige på grund af brugen af præcisionsvåben (Der Derian 2009, xxxi).

I sin læsning af Abrams' roman argumenterer Kristen Rau netop for, at Fobbit samt en række andre amerikanske romaner om Irakkrigen korrigerer "the publicly propagated depiction of the War on Terror as derealized and sanitized." Dette gør de, hævder Rau, "through intensely visceral combat scenes but also through the depiction of the effects of technologically mediated warfare" (Rau 2017, 10), og således argumenterer hun for, at Fobbit fungerer på samme måde som Krig og fred. Men gør den faktisk det? Rau har ret i, at Fobbit viser, hvordan militæret "renser" krigen, men præsenterer romanen sine læsere for krigens beskidte realiteter? Svaret er nej. Handlingen udspiller sig på et tidspunkt, hvor den sekteriske vold i Irak 
eskalerer voldsomt, og selvom Gooding nævner, at mindst to soldater dør om dagen (Abrams 2014, 65), så presser disse realiteter sig ikke på i fremstillingen. De døde amerikanere forbliver abstrakte tal for læseren, og da romanen hovedsageligt udspiller sig inden for basens trygge rammer, så glimrer destruktionen af Irak også ved sit fravær.

Ydermere er det værd at bemærke, at selvom rensningsstrategierne blotlægges, så handler Fobbit netop om, at militæret ikke lykkes med at overbringe deres version af begivenhederne til offentligheden. Sammenlignes historien om pressemeddelelsens livscyklus med fortællingen om Rostóvs ophøjelse til russisk folkehelt, fremgår det tydeligt, at de magtfulde er blevet de magtesløse. I 2005 er militærets forsøg på at kontrollere offentlighedens opfattelse af krigen en fiasko. ${ }^{2}$

Men det er en fiasko uden konsekvenser. Goodings arbejde er ikke kun overflødigt, fordi pressen selv skaffer informationer om begivenhederne. Det viser sig også at være helt unødvendigt, når det kommer til kontrollen med folkestemningen. Hvis det virkelig var så altafgørende at vinde kampen om krigsopfattelsen i medierne, så burde Fobbit fortælle om en tiltagende modvilje mod USAs tilstedeværelse i Irak, men det gør romanen ikke. Handlingen begynder, da Gooding er halvvejs gennem sin etårige udsendelse, og han og kollegaerne omtaler med henvisning til Harold Ramis' film livet på basen som “one big fuckin' Groundhog Day” (Abrams 2014, 14). De 183 dage, som går forud for romanens begyndelse, har været præcis som de dage, læserne får indblik i. Her er ingen krise, som forværres eller forbedres, blot en monoton status quo: "[E]very day is the same thing," skriver Gooding senere i sine dagbogsnotater. "It's like running on a treadmill. [...] Groundhog Day redux" (Abrams 2014, 94).

At Goodings arbejde er overflødigt, bliver ekstra tydeligt, hvis man tager i betragtning, at handlingen udspiller sig på et tidspunkt, hvor det for længst er blevet afsløret, at de masseødelæggelsesvåben, som var en afgørende brik i Bushadministrationens legitimering af og begrundelse for invasionen af Irak, ikke fandtes, og at militæret havde brugt tortur i Abu Ghraib-fængslet. Dette til trods fik den amerikanske befolkning ikke deres æg og brød galt i halsen, forlod morgenbordet og gik på gaderne for at protestere som under Vietnamkrigen. I stedet syntes nyhederne at blive modtaget med en vis portion ligegyldighed. ${ }^{3}$ Eftersom det ingen konsekvenser har, at billedet af krigen løber det amerikanske militær af hænde, så synes Fobbit at tilbagevise Mieszkowskis udsagn om, at det er afgørende at sikre sig kontrollen med "the story in the popular imagination" - i hvert fald når det handler om muligheden for fortsat at kunne føre krig. Blandt dem, der har diskuteret indifferencens årsager, er retshistoriker Samuel Moyn. Konfronteret med den enorme brutalitet i afkoloniseringskrigene efter Anden Verdenskrig begyndte en lang række humanitære organisationer at arbejde for en humanisering af krigen. I stedet for at kritisere krigen som sådan, kritiserede man graden og omfanget af brutaliteten. Som følge heraf blev pacifistiske stemmer mindre markante i den offentlige debat, og fraværet af et generelt nej til krig og markant lavere dødstal har, ifølge Moyn, resulteret i, at den vestlige befolkning i dag i højere grad end tidligere er ude af stand til at forestille sig en verden uden krig og derfor accepterer den endeløse, men lavintense krigstilstand, som Vesten befinder sig i. ${ }^{4}$ Hvis man er overbevist om, at en lavintens, men 
"human" krig er et grundvilkår i det 21. århundrede, så bliver det indlysende nok mindre vigtigt, hvorledes specifikke hændelser fremstilles i medierne.

Det billede af Irakkrigen, som kommer til syne i Fobbit, er på mange måder en gentagelse af det billede, læserne kender fra medierne: kaos, eskalerende sekterisk vold, døde civile irakere og en uendelig række af større og mindre amerikanske fadæser. Hvor Krig og fred udgjorde et korrektiv til den officielle historie, så lægger Abrams' roman sig i forlængelse af eller reproducerer det, vi allerede ved. Tolstojs roman skal ikke blot vise, hvordan de historier om krigen, som fortælles, finder deres form; romanen tilføjer noget nyt og installerer en skepsis i læseren. Men hvordan skal forfatteren så gribe krigen an, når pressen allerede har korrigeret militærets fortælling om krigen? Her synes Abrams' forslag at være den komiske latterliggørelse, for Fobbit er skrevet som en komedie. Romanens personer er, som Walter Benjamin argumenterer for, at det gør sig gældende med komedien, kendetegnet ved ét bestemt karaktertræk. Sagt med andre ord betyder det, at de ikke er kendetegnet ved "en mangfoldighed af karaktertræk", men snarere ved en "menneskets anonymitet": Et indre, psykologisk liv, som ville kunne bruges som forklaring på karakterernes handlinger, er reduceret til fremtrædende træk, og de kommer udelukkende til syne som typer. Disse personlighedstræk - ofte af den mindre flatterende slags som grådighed, hypokondri og misantropi - ville i virkelighedens verden blive mødt med moralsk fordømmelse, men fremvist på komediescenen er de, skriver Benjamin, anledning til stor fornøjelse (Benjamin 1961, 53f). Fobbit er befolket med sådanne typer. Goodings overordnede, Hackleroad, er pralhalsen, der får næseblod, hver gang situationen spidser til (Abrams 2014, 60), mens Kaptajn Shrinkle er den indædte patriot, der dog ender med at skade amerikanerne mere end han gavner dem pga. sin uduelighed. Som konsekvens heraf degraderes Shrinkle til håndklædeansvarlig i hærens fitnesscenter, og ender med - som komediekarakterer ofte gør - at leve op til sit navn, når han sammenkrympet af skam kryber rundt i forsøget på at undgå kontakt med sine tidligere underordnede (Abrams 2014, 218f). Fobbit inviterer sine læsere til at grine af disse personligheder, men hvad kan latteren egentlig?

\section{Fobbit og den komiske latter}

I Fobbit spiller fortællerens mange krasse bemærkninger om personerne en væsentlig rolle for læserens opfattelse af dem og dermed også for den komiske latters karakter. Fra romanens begyndelse gør Abrams' brug af en tell, don't show-taktik. Læserne får ikke lov til at danne deres eget indtryk af karaktererne på baggrund af disses handlinger, i stedet gør fortælleren det klart, hvad læserne skal mene om dem. Romanens åbner med en karakteristik af hovedpersonerne: "They were Fobbits because, at the core, they were nothing but marshmallows." Herefter sammenligner fortælleren fobbitterne ${ }^{5}$ med kaniner, der rystende krymper sig sammen i deres burer, og børn, der klynger sig til deres mors skørter "too scared to venture beyond her grasp" (Abrams 2014, 1). Efter denne generelle karakteristik introduceres Gooding som "the poster child for the stay-back-stay-safe soldier"; en ære som fortælleren tildeler ham pga. hans "lavender-vanilla body wash, and the dust collected around the barrel of his M16 rifle" (Abrams 2014, 2). 
En stærk foragt gennemsyrer disse beskrivelser. Gooding og hans kollegaer er en flok krystere, som ikke lever op til de militære kompetence- og maskulinitetsidealer, men er både barnlige og feminine i deres fremtoning. Det er først og fremmest inkompetence og de personlige særheder - Hackleroads næseblod, Shrinkles patriotrisme, og Durets længsel efter sin hund og konens brystvorte - som læseren inviteres til at le af. Med afsæt i den slovenske filosof Alenka Zupančičs bog om komedien, The Odd One In (2008), kan denne form for komik beskrives som falsk eller konservativ, da latteren er en reaktion på individuelle fejl og mangler. Problemet med denne form for komik er, ifølge Zupančič, at den bestående orden og de ideer og forestillinger, som organiserer det sociale liv, ikke rammes (Zupančič 2008, 30f). Fortællerstemmen i Fobbit sørger for, at læseren griner af en gruppe soldater, mens krigen, militæret og politikken lades uberørt. Eller sagt på en anden vis: Vi griner af fobbitterne, fordi de ikke er militære nok, hvorimod den sande, subversive komedie - for at blive i Zupančičs terminologi - ville få os til at le over selve idéen om militæret, maskulinitet og patriotisme. Den sande komedie sætter spørgsmålstegn ved den bestående orden og viser, at den kun består, fordi vi er tilbøjelige til at agere, som om den var almengyldig og uforanderlig (Zupančič 2008, 31).

En mere subversiv komik toner dog momentvis frem i Fobbit, særligt i de e-mails, Gooding modtager om korrekt sprogbrug, heriblandt mailkorrespondancen om brugen af ordene "insurgent" og "terrorist". Først henstilles der til, at "insurgent" ikke bruges, fordi Irak nu er "a democratic country with an elected transitional government that we so wonderfully helped install. This is no longer a provincial puppet gov't ruled by an evil puppeteer" (Abrams 2014, 158f). Derefter rundsendes en rettelse om, at ordet alligevel ikke skal udgå, før der til sidst kommer en mail, som dikterer at "terrorist" skal erstatte "insurgent" pga. ordets formelle betydning: "a person who revolts against civil authorities or an established government" (Abrams 2014, 161f).

Fraværet af den fordømmende fortæller som medierende instans mellem karakterne og læserne er formentlig en af årsagerne til, at mailkorrespondancen får karakter af subversiv komik. I stedet får den åbenlyse modstrid mellem den første begrundelse for at stoppe brugen "insurgent" og den sidste lov til at stå alene. Først skal ordet udgå, fordi den irakiske overgangsregering er demokratisk valgt, dernæst hedder det sig, at det ikke kan bruges, fordi det vil kræve, at volden er rettet mod civile autoriteter og en etableret regering. At den sidste mail så afsluttes med en bemærkning om, at "kriminel" kan bruges i betydningen af "one who has committed a crime against a lawful government” (Abrams 2014, 161f) gør kun forvirringen total.

Disse mails, der er så optagede af begrebslige definitioner, ender som begrebslig volapyk, og effekten bliver, at det amerikanske militær fremstår som ude af stand til at blive enige med sig selv om den irakiske regerings status og i forlængelse heraf om krigens resultater. De mænd, som skriver mails som ovenstående, er de samme mænd, der fremturer med: "Words are important. Words can wound, maim, and kill" (Abrams 2014, 160). Opfattelsen af, hvor vigtigt presseofficerernes arbejde er, fremstår dog - romanens handling taget i betragtning - som et selvbedrag af dimensioner. På trods af, at det igen og igen viser sig at være overflødigt, så fortsætter militærfolkene ufortrødent, og episoden illustrerer dermed, at systemet ikke opret- 
holdes af nødvendighed, men blot fordi ingen sætter spørgsmålstegnstegn ved dets eksistensberettigelse.

I dansk såvel som i amerikansk kontekst er krigslitteraturen om Irak og Afghanistan blevet kritiseret for at tilsidesætte krigens politik og logik til fordel for historier om hjemvendte soldaters psykiske udfordringer (Rothstein 2014, Beauchamp 2017). Men i Fobbit dukker disse spørgsmål dog op; ikke hele tiden, men momentvis, for i episoderne med mailkorrespondancerne flyttes fokus fra karakterernes individuelle brister til krigens politik. Når ordet "insurgent" fx afvises, fordi "great men like Alexander Hamilton, Henry Clay og Paul Revere" kunne kaldes oprørere, og man for alt i verden ikke ønsker gennem ordvalget at sidestille de irakiske 'terrorister' og "the glorious cause of our nation", så trænger de legitimitetsproblemer, som har kendetegnet Irakkrigen fra begyndelsen, sig på i læsningen på en måde, som de ikke gør, når Fobbit blot gør grin med fobbitternes utilstrækkeligheder.

\section{Hinsides den konservative komik?}

Momenter som dette ændrer dog ikke ved, at Fobbit overordnet set forbliver en konservativ komedie. Som nævnt indledningsvist står Abrams' roman alene blandt en lang række af realistiske fortællinger om krigene i Irak og Afghanistan. Samme tendens gør sig gældende med hensyn til film, hvor David Michôds film War Machine (2017) er en enlig komisk svale. Filmen, der har Brad Pitt i hovedrollen som den firestjernede general Glen McMahon, er baseret på journalist Michael Hastings bog The Operators (2012), som Hastings skrev efter gennem en måned at have fulgt Stanley McChrystal - chefen for den internationale militærstyrke i Afghanistan fra juni 2009 og et år frem. Filmen åbner med en voiceover adresseret til USA:

64 Ah, America. You beacon of composure and proportionate response. You bringer of calm and goodness to the world. What do you do when the war you're fighting just can't possibly be won in any meaningful sense? Well, obviously, you sack the guy not winning it, and you bring in some other guy. In 2009, that war was Afghanistan. And that other guy... was Glen. (Michôd 2017)

Selvom der fra starten lægges op til, at filmen skal være en satirisk kritik af det amerikanske krigsmaskineri, og Glen blot én i rækken af uduelige generaler, så udvikler War Machine sig hurtigt til en film, hvor man ler af Glens særheder. Når han løber gennem lejren som et studie i gakkede gangarter, mens der berettes om hans spartanske rutiner i en af filmens første scener, er det som et forvarsel om hans begrænsede intelligens og inkompetence; træk han i øvrigt deler med sine nærmeste rådgivere. Glen skal være en repræsentant for alle på hans niveau i militæret, men han er så outreret, at han ikke fremstår som en type, men som en ener.

Hvorfor forløser disse forsøg på krigskomik sig ikke i egentlig subversiv latter, når anslaget og intentionen er til stede? En forklaring kunne selvfølgelig være middelmådige roman- og manuskriptforfattere; det skal ikke diskuteres her, men tilfældet vil, at begge værker udtrykker begrænset kritik af militæret. I sit overbliksstudie af amerikanske krigsfilm fra slutningen af Anden Verdenskrig og frem til årtusind- 
skiftet påpeger Richard Slotkin, at officererne ofte viser sig at være inkompetente. De dør eller bliver fjernet fra deres post, hvorefter ansvaret for tropperne overdrages til en "tough veteran sergeant" med lederegenskaber (Slotkin 2001, 491). Anne Mørk genfinder denne antipati for officererne i Steven Spielberg og Tom Hanks tvserie Band of Brothers (2001), hvor foragten hovedsageligt retter sig mod overklassen: folk fra militærakademiet West Point og udygtige kompagnichefer, der kun kan gøre karriere pga. deres forbindelser til ledelsen. De, der forfremmes pga. deres evner, er seriens egentlige helte, og således, skriver Mørk, bliver militæret indbegrebet af det amerikanske ideal om et meritokratisk samfund (Mørk 2011, 64f).

Mens det er åbenlyst, at War Machine med sin spot af generalstaben ligger i forlængelse af denne tendens (Glen er uddannet fra West Point og har en kandidatgrad fra Yale), så er det ikke selvindlysende med Fobbit, da bogen ved første øjekast ikke handler om fodtusserne mod officererne. Dog viser det sig ved nærmere eftersyn, at denne hierarkiske kamp faktisk er et af romanens organiserende principper. Lavest rangerende blandt hovedpersoner er sergent Brock Lumley, der har ansvaret for en deling, som jævnligt er i kamp. Som den eneste introduceres Lumley uden de nedladende beskrivelser, og han deler fortællerens foragt for fobbitterne: "each time he came back from patrol, driving through the main gate of the FOB, his spleen rose between his teeth at the thought of all the coddled soldiers who never went beyond the wire" (Abrams 2014, 41). Lumley bliver romanens repræsentant for de soldater, som må tage til takke med inkompetente oberstløjtnanter og kaptajner som Duret og Shrinkel, samtidig med at de kan se folk som Gooding kravle op ad karrierestigen uden egentlig kamperfaring. Modviljen i Fobbit retter sig således ikke blot opad, men også 'bagud' mod stay-back-stay-safe-soldaterne, der oplever krigen som "a real pain in the ass," fordi opholdet i Irak er som "a yearlong camping trip without the comforts of home (flush toilets, cable TV, sandfree bedsheets) stripped away" (Abrams 2014, 3).

Latteren i Fobbit såvel som i War Machine retter sig altså mod en bestemt gruppe inden for militæret, som vi er kulturhistorisk trænet til at se ned på. Men det er også en ufarlig og konservativ latter, fordi den - som jeg har påpeget ovenfor - ikke sigter mod systemet. I de passager, hvor komikken i Fobbit skifter karakter og med Zupančičs ord bliver mere sand, gentager romanen ikke blot de historier om militære fiaskoer, som kendes fra medierne, eller udfolder en skematisk militærkritik, men udstiller de verdenspolitiske konsekvenser af den amerikanske selvopfattelse. Passager som disse kan give en indikation om, hvordan et mere gennemført subversivt komisk værk ville se ud, samt pege på hvilken historie litteraturen kan fortælle i en tid, hvor militærets fortællinger om krigen allerede er blevet korrigeret.

\section{Noter}

I At det er tilfældet i en dansk kontekst, fremgår tydeligt af Klaus Rothsteins Soldatens år. Afghanistan-krigen i dansk litteratur og kultur (2014). I amerikansk kontekst findes endnu ikke et lignede studie, men den amerikanske ph.d.-studerende David Eislers arbejde bekræfter, at situationen er den samme i USA. Det fremgik af det oplæg “Unburdened: The Influence of the Shift to an 
All-Volunteer Force on American War Fiction", som Eisler holdt på War, Literature \& the Artskonferencen på US Air Force Academy den 21. september 2018. Ligeledes har en række artikler fremhævet samme tendens heriblandt Scott Beauchamps "The Detached Literature of Remote Wars" (2017) og George Packers "Homer Fires" (2014).

2 Romanens udsagn modsiges bl.a. af Roger Luckhurst, der hævder, at militæret med succes har kontrolleret billedet af krigen i medierne. Fotografer, som fulgte soldaterne, var underlagt kontrol ift., hvilke billeder der kunne publiceres. Ifølge Luckhurst forklarer det, hvorfor billeder af lig stort set er fraværende (Luckhurst 2017, 357f). Når det er sagt, så har der, som Fobbit fokuserer på, været mange historier i pressen, som ikke har været til amerikanernes fordel.

3 I sin artikel om amerikansk krigslitteratur diskuterer George Packer civilbefolkningens ligegyldighed og skriver: "Without a draft, without the slightest sacrifice asked of a disengaged public, Iraq put more mental distance between soldiers and civilians than any war of its duration that I can think of" (Packer 2014). Flere skønlitterære værker kommenterer på civilbefolkningens uvidenhed. I Joyce Carol Oates' Carthage (2014) siger kæresten til en hjemvendt soldat: “Operation Iraqi Freedom. Very few people in Carthage know the difference-if there is a difference-between "Iraq" and "Afghanistan." I know: for I am your fiancée and it is necessary for me to know. But still I am confused, and there is no one to ask" (Oates 2014, 22). Ligeledes i Phil Klays novelle "Redeployment" (2014) konstaterer en hjemvendt soldat: "Outside, there're people walking around by the windows like it's no big deal. People who have no idea where Fallujah is, where three members of your platoon died" (Klay 2014, 12).

4 Gengivelsen af Moyns pointer er baseret på forelæsning "Humane: The Politics and Poetics of Endless War", som han gav på Cornell University 17. juli 2018. Da manuskriptet skal indgå i en kommende bog, er det ikke publiceret, men en tidligere version af forelæsningen, "The Rise of Endless War", givet på Oxford University kan høres som podcast (Moyn 2017).

5 Gooding og hans kollegaer kaldes fobbitter, fordi de arbejder på en Forward Operating Base. Romanens epigraf sørger for at lede tankerne hen på Tolkiens hobbitter, der trives bedst i Herred og afskyrr eventyr.

\section{Litteratur}

Abrams, David (2014): Fobbit, London: Vintage.

Aristoteles (2008): Poetikken, Frederiksberg: Det lille Forlag.

Beauchamp (2017): “The Detached Literature of Remote Wars”, American Affairs Journal. https:// americanaffairsjournal.org/2017/08/detached-literature-remote-wars/ (tilgået 16. august 2017). Benjamin, Walter (1961): Illuminationen. Ausgewählte Schriften, Frankfurt: Suhrkamp Verlag. Der Derian, James (2009): Virtuous war: mapping the military-industrial-media-entertainment network, New York: Routledge.

Klay, Phil (2014): Redeployment, New York: The Penguin Press.

Lewis, Adrian R. (2017): The American Culture of War. The History of U.S. Military Force from World War II to Operation Enduring Freedom, New York: Routledge. http://search.ebscohost.com/login.as px?direct $=$ true $\&$ scope $=$ site $\& d b=$ nlebk $\& d b=$ nlabk $\& A N=1592806$.

Luckhurst, Roger (2017): "Iraq War Body Counts: Reportage, Photography, and Fiction", Modern Fiction Studies 63.2, s. 203-224. 
Mieszkowski, Jan (2012): Watching War, Stanford: Stanford University Press. http://site.ebrary. com/id/10583984.

Moyn, Samuel (2017): “The Rise of Endless War", University of Oxford Podcasts, https://podcasts. ox.ac.uk/rise-endless-war.

Mørk, Anne (2011): “'Will this picture help win the war'?': Band of Brothers and the Mythology of World War II", American Studies in Scandinavia 43.2, s. 45-70.

Oates, Joyce Carol (2014): Carthage, London: Fourth Estate.

Packer, George (2014): "Home Fires", The New Yorker 31. marts 2014. https://www.newyorker.com/ magazine/2014/04/07/home-fires-2.

Peebles, Stacey L. (2011): Welcome to the Suck: Narrating the American Soldier's Experience in Iraq, Ithaca: Cornell University Press.

Rau, Kristen (2017): From Frontline to Homefront: The Global Homeland in Contemporary U.S. War Fiction, ph.d.-afhandling ved Department of English, Uppsala: Uppsala University.

Rothstein, Klaus (2014): Soldatens år: Afghanistan-krigen i dansk litteratur og kultur, København: Tiderne Skifter.

Slotkin, Richard (2001): "Unit Pride: Ethnic Platoons and the Myths of American Nationality", American Literary History 13.3, s. 469-498.

Tolstoj, Lev (2004): Krig og fred, b. 2, København: Gyldendals Bogklubber 